\title{
Gossypol Disrupts Embryo Development in Heifers
}

\author{
M. Villaseñor, ${ }^{*}$ A. C. Coscioni, ${ }^{*}$ K. N. Galvão, ${ }^{\star}$ R. C. Chebel, ${ }^{\star}$ and J. E. P. Santos ${ }^{\star} \dagger^{1}$ \\ *School of Veterinary Medicine, University of California-Davis, Tulare 93274 \\ †Department of Animal Sciences, University of Florida, Gainesville 32611
}

\begin{abstract}
Our objectives were to determine the effects of dietary free gossypol (FG) intake on plasma and uterine gossypol concentrations and embryo development and viability before and after culture with gossypol. Fifty postpubertal Holstein heifers weighing $( \pm \mathrm{SD}) 406 \pm 34.5 \mathrm{~kg}$ at 11.5 mo of age were blocked by age and body weight (BW) and randomly assigned to 1 of 3 isocaloric and isonitrogenous diets differing in their FG content: control $(0 \mathrm{mg}$ of $\mathrm{FG} / \mathrm{kg}$ of BW), moderate (17.8 $\mathrm{mg}$ of FG/ $\mathrm{kg}$ of BW), and high (36.8 $\mathrm{mg}$ of FG/kg of BW). Heifers were fed the diets for $70 \mathrm{~d}$ before superovulation and embryo collection. Superovulated heifers were flushed on d 5 after induction of ovulation, and early morulae were either stained, to determine the number and proportion of live and dead cells, or randomly assigned to an in vitro culture for $96 \mathrm{~h}$ in media containing either 0 or $10 \mu \mathrm{g} / \mathrm{mL}$ of gossypol acetic acid. Plasma and uterine gossypol concentrations increased with increasing gossypol intake. The number of low-quality embryos-ova was greater for the high than for the moderate and control diets. Embryos collected from the high diet had the least number of cells because of fewer live cells, and were smaller in diameter. Greater dietary gossypol reduced blastocyst development and extended the time to reach the blastocyst stage. Similarly, gossypol concentration at $10 \mu \mathrm{g} / \mathrm{mL}$ compromised in vitro development and increased the proportion of degenerated embryos at $96 \mathrm{~h}$ in culture. These findings provide in vivo and in vitro evidence that intake of $36.8 \mathrm{mg}$ of FG/ $\mathrm{kg}$ of BW per $\mathrm{d}$ and gossypol concentrations $>7 \mu \mathrm{g} / \mathrm{mL}$ in plasma, in uterine flush, or in vitro compromise early embryo development, which might explain some of the negative effects of gossypol on the fertility of dairy cows. Key words: embryo, gossypol, heifer, reproduction
\end{abstract}

\section{INTRODUCTION}

Cottonseed and its by-products are fed to dairy cattle because of the nutritional value derived from the fat,

Received December 11, 2007.

Accepted March 27, 2008.

${ }^{1}$ Corresponding author: jepsantos@ufl.edu protein, and fiber (NRC, 2001). However, cotton products contain gossypol, a polyphenolic binaphthyl dialdehyde pigment found primarily in the pigment glands present in the cottonseed meats (Robinson et al., 2001), which may be detrimental to mammalian cell metabolism.

The 2 most important cotton species grown in the United States are Upland (Gossypium hirsutum) and Pima (Gossypium barbadense). Pima cottonseed is more nutrient dense than Upland cottonseed, but it contains more total gossypol (TG) and free gossypol (FG) and, because it is delinted and usually fed in a cracked form to cattle, the availability of gossypol from Pima is greater than that from Upland cottonseed (Santos et al., 2005). Therefore, the greater nutritional value of processed Pima cottonseed in diets fed to cattle is compromised by its increased gossypol content and availability; thus, feeding recommendations might differ from those for Upland cottonseed.

One of the potential negative effects of feeding excess FG is a potential decline in the reproductive performance of dairy cows. Santos et al. (2003) demonstrated that as plasma gossypol concentrations increased, the risk for pregnancy in lactating dairy cows fed diets containing different types of cottonseed declined. Furthermore, cows fed the high-FG diet had a reduced rate of pregnancy per AI and increased pregnancy loss. These negative effects of gossypol on fertility were also observed in dairy cows receiving embryos from heifers fed gossypol (Galvão et al., 2006), which suggests that negative effects early in embryo development persist later during maintenance of pregnancy. Coscioni et al. (2003a) observed no effects of increasing FG intake from 0 to $40 \mathrm{mg} / \mathrm{kg}$ of BW on follicle development and luteal function in Holstein heifers; however, feeding gossypol to heifers increased plasma and follicular fluid gossypol concentrations, and heifers consuming $40 \mathrm{mg}$ of FG/kg of BW produced more underdeveloped and degenerated embryos on d 7 after AI (Coscioni et al., 2003a). Depressed fertility caused by gossypol in female cattle might therefore arise from direct or indirect effects on the developing embryo. In fact, work with in vitro-derived embryos has demonstrated the negative effects of gossypol during early embryo development (Zirkle et 
al., 1988; Brocas et al., 1997; Herández-Cerón et al., 2005). Findings by Velasquez-Pereira et al. $(1998,2002)$ indicated long-term accumulation of gossypol in the reproductive tissues of dairy heifers, especially the corpus luteum $(\mathbf{C L})$ and endometrium, possibly because of the lipophilic properties of the molecule, which might accumulate in endometrial phospholipids and lipoproteins, and the cholesterol present in the CL. Because responses in vivo and in vitro might differ, particularly for FG that can be detoxified in the rumen, it is important to determine whether the detrimental effects of gossypol observed with in vitro-produced embryos are also observed with embryos in vivo.

The objectives of this study were to determine the effects of different dietary FG intakes from cracked Pima cottonseed, similar to those commonly observed in lactating dairy cows fed rations containing cottonseed, on embryo development and viability in vivo and in vitro in superovulated Holstein heifers. The hypothesis tested was that gossypol affects early embryo development and viability in vivo and in vitro.

\section{MATERIALS AND METHODS}

\section{Animals, Housing, and Feeding}

Fifty postpubertal Holstein heifers at 11.5 mo of age were housed at the Veterinary Medicine Teaching and Research Center in Tulare, California. The BW of each heifer was determined on beginning the feeding period and again after 30 and $60 \mathrm{~d}$ in feed to calculate the amount of concentrate offered daily to adjust FG intake. Heifers were assigned randomly to 1 of 3 dietary treatments containing graded amounts of gossypol from cracked Pima cottonseed, and were fed for $70 \mathrm{~d}$ before superovulation and embryo collection. Heifers from different treatments were housed together in open corrals, and diets were offered as component fed, with concentrate fed once daily individually to each heifer. The forage component of the diet, a blend of 2:1 of alfalfa and wheat hay mix, was offered for ad libitum intake, and forage intake was monitored daily. The CP and NDF contents of alfalfa hay and wheat hay were, respectively, 23.2 and $35.0 \%$, and 8.5 and $56.4 \%$. Concentrates were offered at $2.2 \mathrm{~kg}$ of $\mathrm{DM} / \mathrm{d}$ per heifer; they were formulated to be isonitrogenous and isocaloric but to vary in TG and FG contents: control $(\mathbf{C}, \mathrm{n}=15 ; 0$ $\mathrm{mg}$ of FG/kg of BW); moderate (M, n $=17 ; 17.8 \mathrm{mg}$ of $\mathrm{FG} / \mathrm{kg}$ of BW); and high ( $\mathrm{H}, \mathrm{n}=18 ; 36.8 \mathrm{mg}$ of $\mathrm{FG} / \mathrm{kg}$ of BW). Diets were offered to meet the nutrient requirements of Holstein heifers weighing $400 \mathrm{~kg}$ and gaining $0.6 \mathrm{~kg} / \mathrm{d}$ (NRC, 2001), considering a daily average forage intake of $4.5 \mathrm{~kg} / \mathrm{heifer}$ based on the mean daily group intake. Descriptions of the concentrates and diets consumed by heifers are given in Table 1 .

Loads of concentrates and hays were sampled and dried at $55^{\circ} \mathrm{C}$ for $48 \mathrm{~h}$ and moisture loss was recorded. Dried samples were ground in a Wiley mill (Arthur H. Thomas Co., Philadelphia, PA), frozen, and later analyzed for DM, OM, ether extract, and CP (AOAC, 2002), NDF (Van Soest et al., 1991), and minerals. Mineral content was determined at the Dairyland Laboratory (Arcadia, WI) by using an ARL inductively coupled plasma emission spectrometer (Thermo Jarrell Ash, Franklin, MA).

\section{Superovulatory Treatment}

The ovulation of heifers was synchronized with the Ovsynch protocol with a progesterone insert: $d$ 0, 100 $\mu \mathrm{g}$ of $\mathrm{GnRH}$ i.m. (Cystorelin, $50 \mu \mathrm{g} / \mathrm{mL}$ of gonadorelin diacetate tetrahydrate, Merial Ltd., Athens, GA) and a controlled internal drug-releasing insert containing progesterone (CIDR, Eazi-Breed, Pfizer Animal Health, New York, NY); d 7, 25 mg of $\mathrm{PGF}_{2 \alpha}$ i.m. (Lutalyse sterile solution, $5 \mathrm{mg} / \mathrm{mL}$ of dinoprost tromethamine, Pfizer Animal Health) and the CIDR removed; d 9, $100 \mu \mathrm{g}$ of GnRH i.m. Ultrasound examination (Aloka SSD 500 V, Aloka Co. Ltd., Tokyo, Japan) of ovarian follicles and CL was performed every $24 \mathrm{~h}$, starting at the $\mathrm{PGF}_{2 \alpha}$ injection, until ovulation was determined. Five days after ovulation, a CIDR was inserted and an i.m. injection of $2 \mathrm{mg}$ of estradiol benzoate ( $\beta$-estradiol,3-benzoate, E-8515, Sigma, St. Louis, MO) was administered $24 \mathrm{~h}$ later. A total of $300 \mathrm{mg}$ of FSH (Folltropin-V, Bioniche Animal Health, Pullman, WA) was used per heifer in 8 i.m. injections in decreasing doses starting at $4 \mathrm{~d}$ after the estradiol benzoate treatment (d 10 after ovulation). Two i.m. injections of $\mathrm{PGF}_{2 \alpha}$ were administered on the seventh and eighth FSH treatments, and the CIDR was removed concomitantly with the last FSH injection. A final injection of $100 \mu \mathrm{g}$ of GnRH was administered $36 \mathrm{~h}$ after CIDR removal to induce ovulation. Heifers were inseminated by the same person twice, $12 \mathrm{~h}$ apart, with the first AI $12 \mathrm{~h}$ after the GnRH treatment. Semen from 2 sires was randomly allocated across all treatments.

\section{Uterine Flush for Embryo Recovery}

The uterine horns of heifers were flushed with approximately $700 \mathrm{~mL}$ of flushing solution (Sterile Filtered Embryo Flushing Solution, PETS Inc., Canton, TX) in a standard nonsurgical procedure on d 5 after induction of ovulation with GnRH. Initially, the embryo-collection catheter was placed in one of the uterine horns 1 to 2 in. cranial to the bifurcation of the uterus, 
Table 1. Ingredient composition and nutrient content of the concentrates, and nutrient content of diets consumed by Holstein heifers $( \pm \mathrm{SD})$

\begin{tabular}{|c|c|c|c|}
\hline \multirow[b]{2}{*}{ Item } & \multicolumn{3}{|c|}{ Dietary treatment ${ }^{1}$} \\
\hline & Control & Moderate & High \\
\hline \multicolumn{4}{|l|}{ Concentrate ingredient } \\
\hline Pima cottonseed, cracked & - & 33.3 & 66.7 \\
\hline Steam-flaked corn, $360 \mathrm{~g} / \mathrm{L}$ & - & - & 22.3 \\
\hline Almond hulls & 44.0 & 35.3 & - \\
\hline Soybean meal, $47 \% \mathrm{CP}$ & 30.0 & 13.3 & - \\
\hline Tallow & 15.0 & 7.1 & - \\
\hline Monensin supplement & 6.7 & 6.7 & 6.7 \\
\hline Minerals and vitamins & 4.3 & 4.3 & 4.3 \\
\hline \multicolumn{4}{|l|}{ Concentrate nutrient content } \\
\hline $\mathrm{OM}, \%$ & $93.7 \pm 1.1$ & $93.2 \pm 0.8$ & $95.0 \pm 0.9$ \\
\hline $\mathrm{CP}, \%$ & $22.8 \pm 0.6$ & $19.4 \pm 0.3$ & $21.0 \pm 0.8$ \\
\hline $\mathrm{ME},{ }^{2} \mathrm{Mcal} / \mathrm{kg}$ & 3.45 & 3.32 & 3.54 \\
\hline NDF, \% & $21.3 \pm 1.8$ & $32.0 \pm 1.1$ & $31.2 \pm 1.4$ \\
\hline Fat, $\%$ & $16.4 \pm 0.8$ & $18.0 \pm 1.1$ & $17.2 \pm 1.0$ \\
\hline $\mathrm{Ca}, \%$ & $0.32 \pm 0.02$ & $0.31 \pm 0.02$ & $0.31 \pm 0.03$ \\
\hline $\mathrm{P}, \%$ & $0.50 \pm 0.02$ & $0.51 \pm 0.02$ & $0.54 \pm 0.01$ \\
\hline $\mathrm{K}, \%$ & $1.81 \pm 0.10$ & $1.54 \pm 0.04$ & $1.51 \pm 0.05$ \\
\hline $\mathrm{Mg}, \%$ & $0.41 \pm 0.02$ & $0.51 \pm 0.02$ & $0.50 \pm 0.02$ \\
\hline $\mathrm{Na}, \%$ & $0.48 \pm 0.01$ & $0.40 \pm 0.02$ & $0.29 \pm 0.01$ \\
\hline $\mathrm{S}, \%$ & $0.13 \pm 0.01$ & $0.21 \pm 0.01$ & $0.25 \pm 0.01$ \\
\hline $\mathrm{Fe}, \mathrm{mg} / \mathrm{kg}$ & $326 \pm 25$ & $206 \pm 35$ & $177 \pm 28$ \\
\hline $\mathrm{Zn}, \mathrm{mg} / \mathrm{kg}$ & $84 \pm 8$ & $94 \pm 12$ & $92 \pm 18$ \\
\hline $\mathrm{Cu}, \mathrm{mg} / \mathrm{kg}$ & $37 \pm 8$ & $35 \pm 5$ & $30 \pm 5$ \\
\hline $\mathrm{Mn}, \mathrm{mg} / \mathrm{kg}$ & $84 \pm 5$ & $114 \pm 6$ & $95 \pm 10$ \\
\hline Monensin, $\mathrm{mg} / \mathrm{kg}$ & 96 & 96 & 96 \\
\hline Total gossypol, ${ }^{3} \mathrm{mg} / \mathrm{kg}$ & 0.0 & 3,496 & 7,003 \\
\hline Free gossypol, ${ }^{3} \mathrm{mg} / \mathrm{kg}$ & 0.0 & 3,333 & 6,670 \\
\hline \multicolumn{4}{|l|}{ Diet nutrient content } \\
\hline $\mathrm{ME}^{2} \mathrm{Mcal} / \mathrm{kg}$ & 2.52 & 2.46 & 2.52 \\
\hline $\mathrm{CP}, \%$ & 20.0 & 19.0 & 19.5 \\
\hline Fat, $\%$ & 6.3 & 6.8 & 6.5 \\
\hline $\mathrm{NDF}, \%$ & 35.3 & 38.5 & 38.3 \\
\hline
\end{tabular}

${ }^{1} \mathrm{Control}=0 \mathrm{mg}$ of free gossypol $/ \mathrm{kg}$ of $\mathrm{BW}$; moderate $=17.8 \mathrm{mg}$ of $\mathrm{FG} / \mathrm{kg}$ of $\mathrm{BW}$; high $=36.8 \mathrm{mg}$ of FG/ $\mathrm{kg}$ of BW.

${ }^{2} \mathrm{ME}=$ metabolizable energy adjusted to $6.7 \mathrm{~kg} / \mathrm{d}$ of DMI (NRC, 2001).

${ }^{3}$ Calculated based on the total and free gossypol concentrations of Pima cottonseed.

and $20 \mathrm{~mL}$ of flushing solution was infused. This first $20 \mathrm{~mL}$ was recovered, and the amount was measured and immediately frozen for later analysis of TG concentration. Afterward, each uterine horn was flushed with approximately $350 \mathrm{~mL}$ of embryo collection solution. Collected embryos-ova were placed in embryo-holding solution and then counted and morphologically evaluated with a stereomicroscope (Nikon SU Z800, Nikon, Melville, NY) for fertilization, and embryos were graded based on quality, according to the International Embryo Transfer Society: 1 = excellent and good; 2 = fair; $3=$ poor; $4=$ degenerate and dead (Stringfellow and Seidel, 1998).

\section{Differential Staining of Cells}

Viable early morulae, grades 1 to 3 , from all dietary treatments were stained with 2 distinct fluorochromes approximately 2.5 to $3.5 \mathrm{~h}$ after collection. Each embryo was individually transferred into a $40-\mu \mathrm{L}$ drop of fluorescein diacetate (FDA; Sigma F7378, Sigma Diagnostics, St. Louis, MO) and propidium iodide (PI; P-1304, Molecular Probes Inc., Eugene, OR) for an incubation of 10 min each (Jones and Senft, 1985). All embryos were washed after each respective stain and then mounted onto microscope slides. The concentrations of FDA and PI working solution were 10 and $5 \mu \mathrm{g} / \mathrm{mL}$, respectively. One drop of a $50 \%$ glycerol solution was placed on a microscope slide before placing the embryo. An epifluorescent microscope was used to count the number of blastomeres stained differentially with FDA and PI. The outer diameter of the zona pellucida of embryos was accessed with a 4-mm linear reticle.

\section{Assignment to Culture Treatments}

Early morulae from all dietary treatments were washed with Ham's F-10 medium in 3 consecutive 45- 
$\mu \mathrm{L}$ drops in a sterile petri dish. Morulae from each treatment were randomly assigned to be cultured in vitro for $96 \mathrm{~h}$ in $45-\mu \mathrm{L}$ drops of medium containing either $0(\mathbf{C M})$ or $10 \mu \mathrm{g} / \mathrm{mL}(\mathbf{G M})$ of gossypol acetic acid (GAA). The CM medium contained $0.1 \%$ ethanol, which was the same concentration used to dilute GAA to 10 $\mu \mathrm{g} / \mathrm{mL}$ in $\mathrm{GM}$.

Ham's F-10 culturing medium was prepared $12 \mathrm{~h}$ before embryo collection. Medium was prepared under sterile conditions and filtered through a sterile, nonpyrogenic $0.2-\mu \mathrm{m}$ syringe filter (190-2520, Fisher Scientific, Pittsburgh, PA) after fetal bovine serum (1614063, Invitrogen, Carlsbad, CA) and antibiotic antimycotic (A5955, Sigma) aliquots were added. Control and GAA medium contained $10 \%$ fetal bovine serum, $1 \%$ antibiotic-antimycotic, and $0.1 \%$ ethanol (D2-82948, Gold Shield Chemical Company, Hayward, CA). The $\mathrm{pH}$ of a subsample of the CM and GM media was measured immediately after preparation and used to ensure a final $\mathrm{pH}$ between 7.1 and 7.4. Embryo culture was performed in gamma-irradiated 4-well vented dishes (PETS Inc.), and the drops were covered with mineral oil (DMPS-2x, Sigma).

Embryos were incubated at $39^{\circ} \mathrm{C}$, in $5 \% \mathrm{CO}_{2}$, and $84.8 \%$ relative humidity. Temperature and relative humidity in the incubator were monitored twice daily with a traceable digital hygrometer-thermometer. Embryos were evaluated every $12 \mathrm{~h}$ and kept covered at all times.

\section{Blood Sample Collection and Analyses of Plasma and Uterine Flush}

Blood samples $(20 \mathrm{~mL})$ were collected from all heifers $24 \mathrm{~h}$ before the day of flushing by puncture of the coccygeal vein or artery with heparinized Vacutainer tubes (Becton Dickinson, Franklin Lakes, NJ). Blood tubes were immediately placed in ice and transported to the laboratory within $1 \mathrm{~h}$ of collection. Tubes were centrifuged at $2,000 \times \mathrm{g}$ for $10 \mathrm{~min}$ at $5^{\circ} \mathrm{C}$ for plasma separation. The plasma was frozen at $-25^{\circ} \mathrm{C}$ for later analyses.

The plasma and uterine flush solution were analyzed for TG and gossypol isomers by HPLC according to a technique described in Mena et al. (2004). Plasma samples were also assayed for concentrations of urea $\mathrm{N}$ (Urea Nitrogen Procedure No. 640, Sigma Diagnostics), glucose by direct measurement with a YSI Model 2700 Select Biochemistry Analyzer (Yellow Springs Instrument Co. Inc., Yellow Springs, OH), NEFA (Johnson and Peters, 1993) with a commercial kit (NEFA C, Wako Chemicals USA Inc., Richmond, VA), and BHBA with a commercial kit (Randox Laboratories Ltd., Antrim, $\mathrm{UK})$.

\section{Experimental Design and Statistical Analysis}

The experimental design was a randomized incomplete block design. Heifers were blocked according to age and BW, and within each block were randomly assigned to 1 of the 3 treatments. For the analyses of embryo development and quality at collection, the donor heifer was considered the experimental unit of analysis. For the analyses of embryo staining immediately after collection, the embryo was used as the experimental unit of analysis. During in vitro culture of embryos, a $3 \times 2$ factorial arrangement of treatments was used, with 3 heifer treatments and 2 embryo culture medium treatments, and embryo was considered the experimental unit of analysis and donor heifer nested within dietary treatment was the random experimental error. Data were tested for normal distribution of the residues by the UNIVARIATE procedure of SAS (SAS/STAT release 9.1, SAS Institute Inc., Cary, NC). The data were assumed to have residues normally distributed when the Shapiro-Wilk statistic was equal to or greater than 0.90 .

Count data, such as number of embryos-ova collected per heifer and number of cells per embryo, were analyzed by the GENMOD procedure by using a Poisson distribution and log-transformation function with the SAS program (SAS/STAT release 9.1). Continuous data with a normal distribution were analyzed by ANOVA with the GLM procedure of SAS (SAS/STAT release 9.1), with a model that included the effects of heifer treatment diet and the random experimental error.

Binary data, such as embryo hatching, compaction, and development into blastocysts, were analyzed by logistic regression with the LOGISTIC procedure of SAS (SAS/STAT release 9.1). Hours of development in vitro was analyzed by ANOVA with the GLM procedure of SAS (SAS/STAT release 9.1). In both cases, the mathematical model included the effects of heifer treatment (C, M, and H), embryo culture medium (CM and GM), the interaction between heifer treatment and embryo culture medium, and donor heifer nested within heifer treatment as the random experimental error.

Data are presented as least squares means and proportions. Treatment differences with $P \leq 0.05$ were considered significant and $0.05<P<0.10$ were considered a tendency.

\section{RESULTS AND DISCUSSION}

\section{Diets and Nutrient Intake}

The concentrations of TG and FG (DM basis) in cracked Pima cottonseed were 1.05 and 1.00, respectively. These results were similar to those observed by others (Robinson et al., 2001; Santos et al., 2002). In 
Table 2. Least squares means for concentrations of total gossypol (TG) and gossypol isomers in the plasma and uterine flush of Holstein heifers fed diets differing in free gossypol (FG) content

\begin{tabular}{|c|c|c|c|c|}
\hline \multirow[b]{2}{*}{ Item } & \multicolumn{3}{|c|}{ Dietary $\mathrm{FG}^{1}$} & \multirow[b]{2}{*}{$P<$} \\
\hline & Control & Moderate & High & \\
\hline \multicolumn{5}{|l|}{ Plasma gossypol, $\mu \mathrm{g} / \mathrm{mL}$} \\
\hline Total & $0.06 \pm 0.38^{\mathrm{a}}$ & $4.07 \pm 0.39^{b}$ & $7.03 \pm 0.35^{\mathrm{c}}$ & 0.0001 \\
\hline (+) isomer & $0.03 \pm 0.14^{\mathrm{a}}$ & $1.50 \pm 0.14^{\mathrm{b}}$ & $2.67 \pm 0.13^{\mathrm{c}}$ & 0.0001 \\
\hline$(-)$ isomer & $0.03 \pm 0.25^{\mathrm{a}}$ & $2.58 \pm 0.26^{\mathrm{b}}$ & $4.36 \pm 0.23^{\mathrm{c}}$ & 0.0001 \\
\hline \multicolumn{5}{|l|}{ Isomer, \% of TG } \\
\hline$(+)$ isomer & $46.0 \pm 2.51^{\mathrm{a}}$ & $36.7 \pm 0.95^{\mathrm{b}}$ & $38.4 \pm 0.84^{\mathrm{b}}$ & 0.01 \\
\hline$(-)$ isomer & $54.0 \pm 2.51^{\mathrm{a}}$ & $63.3 \pm 0.95^{\mathrm{b}}$ & $61.6 \pm 0.84^{b}$ & 0.01 \\
\hline \multicolumn{5}{|l|}{ Uterine fluid gossypol } \\
\hline Amount recovered, ${ }^{2} \mathrm{~mL}$ & $8.9 \pm 0.2$ & $8.8 \pm 0.1$ & $8.9 \pm 0.2$ & 0.78 \\
\hline Total, $\mu \mathrm{g} / \mathrm{mL}$ & $0.02 \pm 0.01^{\mathrm{a}}$ & $3.02 \pm 0.28^{b}$ & $7.21 \pm 0.48^{\mathrm{c}}$ & 0.001 \\
\hline$(+)$ isomer, \% & $48.0 \pm 3.22^{\mathrm{a}}$ & $37.2 \pm 0.88^{\mathrm{b}}$ & $36.3 \pm 0.96^{\mathrm{b}}$ & 0.01 \\
\hline$(-)$ isomer, \% & $52.1 \pm 3.22^{\mathrm{a}}$ & $62.9 \pm 0.88^{\mathrm{b}}$ & $63.7 \pm 0.96^{\mathrm{b}}$ & 0.01 \\
\hline
\end{tabular}

${ }^{\mathrm{a}-\mathrm{c}}$ Mean values with different superscripts in the same row differ $(P<0.01)$.

${ }^{1} \mathrm{Control}=0 \mathrm{mg}$ of FG/kg of BW; moderate $=17.8 \mathrm{mg}$ of FG $/ \mathrm{kg}$ of BW; high $=36.8 \mathrm{mg}$ of FG/kg of BW.

${ }^{2}$ First $20 \mathrm{~mL}$ of uterine flush solution infused and recovered for analysis from heifers. A portion was left in the embryo filter to ensure that embryos would not be retained in the filter with no flush solution.

fact, the variability in gossypol content of different varieties of Pima cottonseed is small (Robinson et al., 2001). Heifers receiving the $\mathrm{M}$ and $\mathrm{H}$ diets consumed 7.3 and $14.7 \mathrm{~g}$ of FG/d, respectively, which resulted in an average FG intake of 17.8 and $36.8 \mathrm{mg} / \mathrm{kg}$ of BW per $\mathrm{d}$. These quantities were slightly less than the initially intended FG intakes of 20 and $40 \mathrm{mg} / \mathrm{kg}$ of BW per d, for $\mathrm{M}$ and $\mathrm{H}$, respectively. Nutrient contents of concentrates were similar (Table 1), which resulted in similar concentrations of $\mathrm{CP}, \mathrm{NDF}$, and fat in the ration consumed by heifers (Table 1).

\section{Gossypol Concentrations}

Plasma gossypol concentrations increased $(P<0.001)$ as FG intake increased (Table 2). As expected, heifers fed $\mathrm{C}$ had almost undetectable TG in plasma. In fact, only 2 of the $\mathrm{C}$ heifers had detectable gossypol in plasma. Similar to TG, the concentrations of the $(+)$ and the $(-)$ isomers were greater $(P<0.001)$ for $\mathrm{H}$ than $\mathrm{M}$, and for $\mathrm{M}$ than $\mathrm{C}$ heifers. Because Pima contains a slightly larger proportion of TG as the (-) isomer (Robinson et al., 2001; Santos et al., 2002, 2003), the $(-)$ isomer in plasma usually increases to a greater extent than the (+) isomer (McCaughey et al., 2005; Santos et al., 2005), which might suggest that retention or metabolism of the 2 gossypol isomers differ. Because of such differences, heifers fed the $\mathrm{M}$ and $\mathrm{H}$ diets were expected to have more (-) than (+) isomer in plasma, as was observed previously (Santos et al., 2002, 2005; McCaughey et al., 2005).

The study was originally designed to result in plasma TG concentrations of approximately 0,5 , and $10 \mu \mathrm{g} / \mathrm{mL}$ for the $\mathrm{C}, \mathrm{M}$, and $\mathrm{H}$ treatments, respectively. This was based on estimated FG intakes and plasma gossypol concentrations in lactating dairy cows from previous studies (Santos et al., 2002, 2003). In those studies, lactating cows were consuming approximately $24 \mathrm{~kg}$ of $\mathrm{DM} / \mathrm{d}$, which represents approximately 3.5 to $4.0 \%$ of their BW, considering an estimated 600 to $650 \mathrm{~kg}$ of BW for Holstein cows. Mena et al. (2004) suggested that changes in the retention time of feeds might affect gossypol detoxification within the rumen, which affects plasma gossypol concentrations. In the current study, heifers were consuming DM at only $1.7 \%$ of their BW, which should increase the rumen retention time relative to that of a lactating cow consuming DM at 3.5 to $4.0 \%$, therefore increasing the rumen detoxification of FG. In addition, dietary Fe content might have influenced plasma gossypol concentrations because $\mathrm{Fe}$ has been shown to reduce the availability of gossypol for absorption (McCaughey et al., 2005; Santos et al., 2005). These differences between lactating cows and heifers and the $\mathrm{Fe}$ content of the rations might explain the slightly smaller plasma TG concentrations than initially expected. Nevertheless, concentrations of gossypol in plasma increased in parallel with dietary FG intake.

Of the first $20 \mathrm{~mL}$ infused in the uteri of heifers, a similar amount was recovered for each treatment (Table 2). The remainder of the fluid was left in the filter to ensure that embryos were not left without any flush solution. It is interesting to note that gossypol concentrations in the initial $20 \mathrm{~mL}$ of uterine flush infused and recovered paralleled those of plasma in heifers. Concentrations of gossypol in reproductive tissues of cows have not been described well. To our knowledge, only Velasquez-Pereira et al. (2002) reported gossypol 
Table 3. Least squares means for BW and concentrations of metabolites in the plasma of Holstein heifers fed diets differing in free gossypol (FG) content

\begin{tabular}{lcccr}
\hline & \multicolumn{3}{c}{ Dietary $\mathrm{FG}^{1}$} \\
\cline { 2 - 4 } Item & Control & Moderate & High & $P<$ \\
\hline BW, kg & $400.5 \pm 10.5$ & $415.5 \pm 10.5$ & $402.2 \pm 10.5$ & 0.55 \\
Urea N, mg/dL & $15.9 \pm 0.8$ & $16.5 \pm 0.7$ & $16.3 \pm 1.1$ & 0.37 \\
Glucose, mg/dL & $62.3 \pm 0.6$ & $61.4 \pm 0.7$ & $63.1 \pm 0.9$ & 0.22 \\
NEFA, $\mu \mathrm{Eq} / \mathrm{L}$ & $193 \pm 11$ & $198 \pm 22$ & $213 \pm 24$ & 0.18 \\
BHBA, mg/dL & $2.2 \pm 0.4$ & $2.6 \pm 0.3$ & $2.5 \pm 0.2$ & 0.62 \\
\hline
\end{tabular}

${ }^{1}$ Control $=0 \mathrm{mg}$ of FG/kg of BW; moderate $=17.8 \mathrm{mg}$ of $\mathrm{FG} / \mathrm{kg}$ of BW; high $=36.8 \mathrm{mg}$ of FG/kg of BW.

concentrations in reproductive tissues of beef heifers consuming up to $16.5 \mathrm{mg}$ of FG/kg of BW per d. The authors observed that both the endometrium and the CL had very high concentrations of TG (Velasquez-Pereira et al., 2002), indicating that gossypol accumulates in the reproductive tract of heifers. In fact, concentrations of gossypol in the endometrium ranged from 78 to $87 \mathrm{mg} / \mathrm{kg}$ of tissue, which were much greater than concentrations observed in plasma (Velasquez-Pereira et al., 2002). In the current study, uterine tissue was not collected, but uterine flush concentrations paralleled those of plasma gossypol concentrations, and heifers fed $\mathrm{H}$ had both plasma and uterine flush gossypol concentrations that have been shown to suppress embryonic development in vitro (Brocas et al., 1997). It is unknown whether gossypol concentrations in the uterine flush would remain constant throughout the embryo collection procedure or if the concentrations measured in the initial $20 \mathrm{~mL}$ of flush solution truly represent the quantities of gossypol that embryos are exposed to during their development in the uteri of cows fed cottonseed. Nevertheless, concentrations differed among treatments in a dose-response manner, which suggests that feeding FG increases TG concentrations in the uterine lumen, thereby exposing gametes and embryos to increased gossypol concentrations. Indeed, feeding increased amounts of FG to heifers increased plasma and follicular fluid gossypol concentrations in a parallel manner (Coscioni et al., 2003b).

\section{Plasma Metabolites and BW}

Because heifers receiving $\mathrm{H}$ had to be fed a large quantity of cottonseed to achieve the desired FG intakes, concentrations of $\mathrm{CP}$ and fat in the ration consumed (Table 1) were greater than typically recommended for this group of animals (NRC, 2001). Body weights throughout the study were similar among dietary treatments, averaging $406.1 \mathrm{~kg}$ (Table 3).

Blood metabolites were measured to determine whether the different dietary treatments would result in differences in metabolic profiles of donor heifers that might potentially affect embryo quality (Table 3). Concentrations of urea N, glucose, NEFA, and BHBA were similar $(P>0.10)$ for all treatments. Although not within the scope of this study, excessive intake of energy and protein can negatively affect embryo quality in cattle (Santos et al., 2008). Heifers fed protein in excess by adding urea to the ration had increased concentrations of urea $\mathrm{N}$ in plasma, reduced uterine $\mathrm{pH}$, and reduced pregnancy per AI (Elrod and Butler, 1993). It is possible that embryo quality might not have been optimized in the current study because heifers had to be fed diets with increased nutrient concentrations to achieve the desirable FG intake. Nevertheless, dietary treatments resulted in similar nutrient intakes, BW, and plasma concentrations of metabolites.

\section{Gossypol Intake on Superovulatory Response and Recovery of Embryos-Ova}

Superovulatory response based on the number of CL observed by ultrasonography was less $(P=0.02)$ for heifers receiving the $\mathrm{C}$ diet than the $\mathrm{M}$ diet, but did not differ from those receiving the $\mathrm{H}$ diet (Table 4). Dietary FG intake did not influence the number of embryos-ova and embryos collected, and percentage of recovery. Coscioni et al. (2003b) evaluated superovulatory responses and recovery efficiency by using similar treatments and found no effect of gossypol intake on the number of ovulations and the number or proportion of embryos-ova recovered. Although the superovulatory response seemed to have been reduced in heifers fed C, the number of embryos-ova and only embryos collected and the proportion of recovery were not influenced by dietary FG.

Dietary nutrient intake is one of the factors that contributes to the variability in superovulatory response, and excess nutrient intake depresses the superstimulatory response and subsequent embryo quality (Santos et al., 2008). Despite the similar energy and protein content of all 3 diets, our experimental design resulted in diets with excessive concentrations of fat and protein, which might have had an overall reduction in superovu- 
Table 4. Effect of free gossypol (FG) intake on superovulatory response embryo quality in Holstein heifers

\begin{tabular}{lcccr}
\hline & \multicolumn{3}{c}{ Dietary FG ${ }^{1}$} \\
\cline { 2 - 4 } Item & Control & Moderate & High & $P<$ \\
\hline Heifers, n & 15 & 17 & 18 & - \\
Corpora lutea, n/heifer & $6.5^{\mathrm{a}}$ & $9.4^{\mathrm{b}}$ & $8.0^{\mathrm{ab}}$ & 0.02 \\
Embryos-ova, n/heifer & 5.4 & 5.4 & 6.6 & 0.23 \\
Recovery, \% $( \pm$ SEM) & $78.1 \pm 10.4$ & $56.6 \pm 9.1$ & $79.3 \pm 9.4$ & 0.17 \\
Embryos, n/heifer & 4.4 & 5.2 & 5.7 & 0.27 \\
Grades 1 and 2, n & 2.60 & 2.94 & 2.67 & 0.82 \\
Grades 1 and 2, \% & $48.7 \pm 9.5$ & $53.5 \pm 9.5$ & $46.1 \pm 8.5$ & 0.84 \\
Degenerated-dead, n & $1.13^{\mathrm{a}}$ & $1.35^{\mathrm{a}}$ & $2.50^{\mathrm{b}}$ & 0.01 \\
Degenerated-dead, \% & $27.0 \pm 7.9$ & $20.5 \pm 7.9$ & $29.1 \pm 7.0$ & 0.71 \\
Grades 3, 4, and unfertilized, n & $2.80^{\mathrm{a}}$ & $2.41^{\mathrm{a}}$ & $3.94^{\mathrm{b}}$ & 0.03 \\
Grades 3, 4 and unfertilized, \% & $51.3 \pm 9.5$ & $46.5 \pm 9.5$ & $53.9 \pm 8.5$ & 0.84 \\
\hline
\end{tabular}

${ }^{\mathrm{a}, \mathrm{b}}$ Mean values with different superscripts in the same row differ $(P<0.05)$.

${ }^{1} \mathrm{Control}=0 \mathrm{mg}$ of FG/kg of BW; moderate = $17.8 \mathrm{mg}$ of FG/kg of BW; high = $36.8 \mathrm{mg}$ of FG/kg of BW.

lation and number of embryos-ova collected (Santos et al., 2008).

Dietary treatment did not affect the number of grades 1 and 2 embryos collected from heifers (Table 4). The number of degenerated embryos was similar between $\mathrm{C}$ and $\mathrm{M}$ heifers, but heifers fed $\mathrm{H}$ had an increased $(P=0.01)$ number of degenerated embryos. In fact, the numbers of unfertilized and low-quality embryos were greater $(P=0.03)$ for heifers fed $\mathrm{H}$ than for those fed $\mathrm{C}$ or M. Because gossypol alters lipid membrane conductance, which increases proton permeability, it can disrupt cell metabolism by altering the influx of ions into the cytoplasm and mitochondria of the cell (Reyes et al., 1984). When cows were fed gossypol, erythrocyte fragility increased (Velasquez-Pereira et al., 1998, 2002; Mena et al., 2004), which indicates changes in cell membrane integrity. Concentrations of gossypol in reproductive tissues were found to be higher than those commonly found in plasma when heifers were fed 14 $\mathrm{mg}$ of FG/kg of BW from cottonseed meal (VelasquezPereira et al., 2002). Such high concentrations of gossypol in reproductive tissues could result in disruption of cell membrane integrity in the early developing embryo, as has been demonstrated with erythrocytes. In fact, concentrations of gossypol in the plasma and uterine flush of heifers fed $\mathrm{H}$ were similar to those observed in the plasma of lactating cows with reduced pregnancy per AI (Santos et al., 2003), and of donor heifers that produced embryos with compromised ability to maintain pregnancy after embryos were transferred into lactating cows (Galvão et al., 2006). The changes in gossypol concentrations in reproductive tissues could account for the increased number of low-quality embryos-ova observed in this study when superovulated Holstein heifers were fed $36.8 \mathrm{mg}$ of FG/kg of BW.

\section{Gossypol Intake and Embryo Characteristics by Differential Staining}

A total of 72 viable early morulae were stained immediately after collection, 23 from $\mathrm{C}, 28$ from $\mathrm{M}$, and 21 from $\mathrm{H}$ heifers. The grade quality of morulae from different treatments was similar before staining (Table 5 ). The numbers of cells were similar for $\mathrm{C}$ and $\mathrm{M}$, but embryos from heifers fed $\mathrm{H}$ had fewer $(P<0.01)$ cells, primarily because of a reduced $(P=0.01)$ number of live cells. Furthermore, embryos from heifers fed $\mathrm{H}$ were smaller $(P<0.001)$ in diameter than embryos from heifers fed $\mathrm{C}$ and $\mathrm{M}$.

In vitro-derived embryos usually have compromised development when cultured in the presence of gossypol (Zirkle et al., 1988; Brocas et al., 1997), and this negative effect seems to be pronounced in the first stages of embryonic development (Hernández-Cerón et al., 2005). Although it was not possible to assess cleavage rate in vivo, one possibility for the retarded development of embryos from heifers fed $\mathrm{H}$ was a potential delayed cleavage compared with their counterparts from $\mathrm{C}$ and $\mathrm{M}$; however, when presumptive 1-celled embryos were cultured in medium containing gossypol, cleavage rate was not altered, but percentages of 1celled embryos developing to blastocysts on $8 \mathrm{~d}$ after insemination were markedly reduced, at $10 \mu \mathrm{g} / \mathrm{mL}$ of gossypol in the culture medium (Hernández-Cerón et al., 2005). Randel et al. (1996) did not detect marked effects of gossypol intake on embryo quality by direct evaluation of morphology when using stereoscopes. Others also found no differences in the development of embryos from beef heifers fed cottonseed meal (Velasquez-Pereira et al., 2002). Interestingly, intakes of 17.8 $\mathrm{mg}$ of FG/kg of BW, resulting in plasma gossypol concentrations of $4.07 \mu \mathrm{g} / \mathrm{mL}$ and uterine flush gossypol concentration of $3.02 \mu \mathrm{g} / \mathrm{mL}$, did not seem to have any 
VILLASEÑOR ET AL.

Table 5. Effect of free gossypol (FG) intake on embryo characteristics during staining $( \pm \mathrm{SEM})$

\begin{tabular}{lcccc}
\hline & \multicolumn{4}{c}{ Dietary FG ${ }^{1}$} \\
\cline { 2 - 4 } Item & Control & Moderate & High & $P<$ \\
\hline Early morulae, $\mathrm{n}$ & 23 & 28 & 21 & - \\
Initial grade quality, 1 to 3 & $2.2 \pm 0.30$ & $2.3 \pm 0.27$ & $1.6 \pm 0.31$ & 0.31 \\
Blastomeres, n & & & & 0.01 \\
Total & $25.4^{\mathrm{a}} \pm 1.8$ & $27.8^{\mathrm{a}} \pm 2.1$ & $19.6^{\mathrm{b}} \pm 1.6$ & 0.01 \\
Live & $21.3^{\mathrm{a}} \pm 1.5$ & $22.8^{\mathrm{a}} \pm 1.6$ & $15.4^{\mathrm{b}} \pm 1.2$ & 0.57 \\
Dead & $4.2 \pm 1.3$ & $4.7 \pm 1.6$ & $4.2 \pm 1.2$ & 0.95 \\
Live blastomeres, \% & $83.8 \pm 5.7$ & $82.0 \pm 5.1$ & $78.6 \pm 7.5$ & \\
Embryo diameter, $\mu \mathrm{m}$ & $199.2^{\mathrm{a}} \pm 2.9$ & $191.5^{\mathrm{b}} \pm 2.5$ & $179.4^{\mathrm{c}} \pm 3.4$ & 0.001 \\
\hline a-c Mean values with different superscripts in the same row differ $(P<0.01)$. & & \\
${ }^{1}$ Control = 0 mg of FG/kg of BW; moderate $=17.8 \mathrm{mg}$ of FG/kg of BW; high $=36.8 \mathrm{mg}$ of FG/kg of BW.
\end{tabular}

deleterious effect on embryo development in vivo. Thus, feeding $17.8 \mathrm{mg}$ of FG/kg of BW from cracked Pima cottonseed, to result in a plasma TG concentration of $4 \mu \mathrm{g} / \mathrm{mL}$, may be a threshold level to consider in the diet to avoid compromised early embryo development. A reduction in embryo diameter based on the diameter of the zona pellucida potentially indicates the effects of gossypol on the oocyte. Feeding heifers diets with similar concentrations of gossypol increased plasma and follicular fluid gossypol concentrations (Coscioni et al., $2003 \mathrm{~b}$ ). The presence of gossypol in the follicular fluid indicates that oocytes developed in the presence of gossypol when heifers were fed cottonseed, which could have resulted in the differences in morula diameter observed in the current study. Cell population and embryo diameter differed among treatments (Table 5), which indicates that embryo development in vivo was impaired when heifers were fed $36.8 \mathrm{mg}$ of FG/kg of BW.

\section{Gossypol Intake and In Vitro Concentration of GAA on Embryo Development In Vitro}

A total of 103 morulae were cultured in vitro, $29 \mathrm{C}$ (15 CM, $14 \mathrm{GM}), 35 \mathrm{M}$ (19 CM, $16 \mathrm{GM})$, and $39 \mathrm{H}$ (21 CM, $18 \mathrm{GM})$. Because no interaction $(P>0.20)$ between embryo donor dietary FG content and in vitro GAA concentration was observed in any of the outcomes evaluated, data are presented separately for the effects of dietary FG and in vitro gossypol concentrations (Table 6). Proportion of embryos compacting was not affected by dietary FG intake or in vitro incubation with GAA. Compaction of the embryonic cells, which occurs 5 to 6 $\mathrm{d}$ after fertilization, is a necessary developmental process to the formation of the blastocyst (Gordon, 1994). Such a process describes the formation of tight junctions between cells, which is necessary for the expansion of the blastocoele cavity through the accumulation of fluid, which is energy dependent (Van Soom et al., 1996).
Although dietary FG had no effect on compaction, it tended $(P=0.09)$ to decrease the proportion of morulae that transitioned into the blastocyst stage after $96 \mathrm{~h}$ of culture. Fewer $(P<0.05)$ embryos from $\mathrm{H}$ heifers developed to the blastocyst stage than $\mathrm{C}$ and $\mathrm{M}$ embryos. Furthermore, embryos from $\mathrm{H}$ heifers took longer $(P=0.02)$ to develop to blastocysts than did $\mathrm{C}$ and $\mathrm{M}$ embryos. Similar to the high dietary FG that reduced blastocyst formation, in vitro culture in a medium containing $10 \mu \mathrm{g} / \mathrm{mL}$ of GAA also tended $(P=0.10)$ to reduce development to the blastocyst stage. Zirkle et al. (1988) reported a smaller proportion of morulae that transitioned to the blastocyst stage at $10 \mu \mathrm{g} / \mathrm{mL}$ of GAA, and no morulae reached the blastocyst stage when the culture medium contained $30 \mu \mathrm{g} / \mathrm{mL}$ of GAA. Reyes et al. (1984) demonstrated that gossypol interacts with lipid membranes, and suggested that energy generation from mitochondrial activity may be disrupted in cells exposed to gossypol; others have found that gossypol increases erythrocyte membrane fragility (VelasquezPereira et al., 1998, 2002; Mena et al., 2004). Because gossypol interacts with lipid membranes and disrupts ion transport in mitochondria and other organelles, it is reasonable to speculate it might also interfere with the formation of the tight junctions that are necessary for cell-to-cell communication in the developing embryo, as well as generation of the energy necessary for embryo metabolism and formation of the blastocoele cavity. These effects might delay or interrupt embryo development, as observed in the current study and in other in vitro studies (Zirkle et al., 1988; Brocas et al., 1997).

Although the presence of gossypol at $10 \mu \mathrm{g} / \mathrm{mL}$ tended to reduce the proportion of early morulae that reached the blastocyst stage, embryos in GM that developed to blastocyst reached that stage sooner $(P=0.02)$ than embryos from CM. Nevertheless, embryos cultured in GM developed for fewer $(P=0.02)$ hours in vitro than embryos cultured in CM. We did not anticipate that GM embryos would reach the blastocyst stage earlier 
Table 6. Effect of free gossypol (FG) intake and in vitro concentration of gossypol acetic acid (GAA) on embryo development in vitro $( \pm \mathrm{SEM})$

\begin{tabular}{|c|c|c|c|c|c|c|c|}
\hline \multirow[b]{3}{*}{ Item } & \multicolumn{5}{|c|}{ Treatment } & \multirow{2}{*}{\multicolumn{2}{|c|}{$P<$}} \\
\hline & \multicolumn{3}{|c|}{ Dietary $\mathrm{FG}^{1}$} & \multicolumn{2}{|c|}{ In vitro GAA, $\mu \mathrm{g} / \mathrm{mL}$} & & \\
\hline & Control & Moderate & High & 0.0 & 10.0 & FG & GAA \\
\hline Compaction, \% & 90.3 & 89.5 & 85.7 & 91.5 & 84.6 & 0.73 & 0.22 \\
\hline Blastocyst, $\%$ & $51.6^{\mathrm{a}}$ & $55.3^{\mathrm{a}}$ & $33.3^{\mathrm{b}}$ & 50.9 & 40.4 & 0.09 & 0.10 \\
\hline Hours to blastocyst & $33.9^{\mathrm{a}} \pm 6.0$ & $33.5^{\mathrm{a}} \pm 4.9$ & $53.4^{\mathrm{b}} \pm 6.0$ & $48.1 \pm 4.1$ & $32.5 \pm 5.1$ & 0.02 & 0.02 \\
\hline Development in vitro, $h$ & $70.7 \pm 4.8$ & $78.1 \pm 4.4$ & $68.1 \pm 4.2$ & $78.3 \pm 3.5$ & $66.2 \pm 3.7$ & 0.24 & 0.02 \\
\hline Degenerated at $96 \mathrm{~h}, \%$ & 42.0 & 40.8 & 53.5 & 33.9 & 59.7 & 0.38 & 0.04 \\
\hline
\end{tabular}

${ }^{\mathrm{a}, \mathrm{b}}$ Mean values with different superscripts in the same row differ $(P<0.05)$.

${ }^{1} \mathrm{Control}=0 \mathrm{mg}$ of FG/kg of BW; moderate $=17.8 \mathrm{mg}$ of FG/kg of BW; high $=36.8 \mathrm{mg}$ of FG/kg of BW.

than embryos cultured in CM. In any case, it was clear that both FG intake at $36.8 \mathrm{mg} / \mathrm{kg}$ of $\mathrm{BW}$ and the presence of gossypol at $10 \mu \mathrm{g} / \mathrm{mL}$ in the embryo culture medium compromised early embryo development.

\section{CONCLUSIONS}

Increasing FG intake resulted in increased gossypol concentrations in plasma and uterine flush to values previously reported to be detrimental to the fertility of lactating dairy cows. Feeding cracked Pima cottonseed to supply FG at $36.8 \mathrm{mg} / \mathrm{kg}$ of BW per d compromised the quality and viability of 5-d-old embryos in vivo. The negative effects of gossypol on subsequent embryo development up to $96 \mathrm{~h}$ of in vitro culture at a gossypol concentration similar to that found in the plasma of dairy cattle fed cottonseed was observed regardless of embryo donor treatment, which demonstrates that the early bovine embryo was susceptible to the negative effects of gossypol at different stages of development. Results from this study support the concept that consumption of $36.8 \mathrm{mg}$ of FG/kg of BW and gossypol concentrations $>7 \mu \mathrm{g} / \mathrm{mL}$ reduce embryo development in vivo and in vitro, which might explain the negative effects of gossypol on the fertility of dairy cows.

\section{REFERENCES}

AOAC. 2002. Official Methods of Analysis. 18th ed. Assoc. Off. Anal. Chem., Arlington, VA.

Brocas, C., R. M. Rivera, F. F. Paula-Lopes, L. R. McDowell, M. C. Calhoun, C. R. Staples, N. S. Wilkinson, A. J. Boning, P. J. Chenoweth, and P. J. Hansen. 1997. Deleterious actions of gossypol on bovine spermatozoa, oocytes, and embryos. Biol. Reprod. 57:901-907.

Coscioni, A. C., M. Villaseñor, K. N. Galvão, J. E. P. Santos, B. Puschner, and L. M. C. Pegoraro. 2003a. Effect of gossypol intake and plasma gossypol concentrations on follicle development and luteal function in dairy heifers. J. Dairy Sci. 86(Suppl. 1):240. (Abstr.)

Coscioni, A. C., M. Villaseñor, K. N. Galvão, R. Chebel, J. E. P. Santos, J. H. Kirk, B. Puschner, and L. M. C. Pegoraro. 2003b. Effect of gossypol intake on plasma and uterine gossypol concentrations and on embryo quality and development in superovulated Holstein dairy heifers. J. Dairy Sci. 86(Suppl. 1):240. (Abstr.)
Elrod, C. C., and W. R. Butler. 1993. Reduction of fertility and alteration of uterine $\mathrm{pH}$ in heifers fed excess ruminally degradable protein. J. Anim. Sci. 71:694-701.

Galvão, K. N., J. E. P. Santos, A. C. Coscioni, S. O. Juchem, R. C. Chebel, W. M. Sischo, and M. Viallaseñor. 2006. Embryo survival from gossypol-fed heifers after transfer to lactating cows treated with human chorionic gonadotropin. J. Dairy Sci. 89:2056-2064.

Gordon, I. 1994. Laboratory Production of Cattle Embryos. CAB International, Wallingford, UK.

Hernández-Cerón, J., F. D. Jousan, P. Soto, and P. J. Hansen. 2005. Timing of inhibitory actions of gossypol on cultured bovine embryos. J. Dairy Sci. 88:922-928.

Johnson, M. M., and J. P. Peters. 1993. Technical note: An improved method to quantify nonesterified fatty acids in bovine plasma. J. Anim. Sci. 71:753-756.

Jones, K. H., and J. A. Senft. 1985. An improved method to determine cell viability by simultaneous staining with fluorescein diacetatepropidium iodide. J. Histochem. Cytochem. 33:77-79.

McCaughey, K.M., E. J. DePeters, P. H. Robinson, J. E. P. Santos, S. J. Taylor, and J. W. Pareas. 2005. Impact of feeding whole Upland cottonseed, with or without cracked Pima cottonseed with increasing addition of iron sulfate, on milk and milk fat composition of lactating dairy cattle. Anim. Feed Sci. Technol. 123124:667-685.

Mena, H., J. E. P. Santos, J. T. Huber, M. Tarazon, and M. C. Calhoun. 2004. The effects of varying gossypol intake from whole cottonseed and cottonseed meal on lactation and blood parameters in lactating dairy cows. J. Dairy Sci. 87:2506-2518.

NRC. 2001. Nutrient Requirements of Dairy Cattle. 7 th rev. ed., Natl. Acad. Sci. Washington, DC.

Randel, R. D., S. T. Willard, S. J. Wyse, and L. N. French. 1996. Effects of diets containing free gossypol on follicular development, embryo recovery and corpus luteum function in Brangus heifer treated with bFSH. Theriogenology 45:911-922.

Reyes, J., J. Allen, N. Tanphaichitr, A. R. Bellvé, and D. J. Benos. 1984. Molecular Mechanism of gossypol action on lipid membranes. J. Biol. Chem. 259:9607-9615.

Robinson, P. H., G. Getachew, E. J. DePeters, and M. C. Calhoun. 2001. Influence of variety and storage for up to 22 days on nutrient composition and gossypol level in Pima cottonseed (Gossypium spp.). Anim. Feed Sci. Technol. 91:149-156.

Santos, J. E. P., R. L. A. Cerri, and R. Sartori. 2008. Nutritional management of the donor cow. Theriogenology 69:88-97.

Santos, J. E. P., H. Mena, J. T. Huber, and M. Tarazon. 2005. Effect of source of gossypol and iron supplementation on plasma gossypol concentrations and performance of growing Holstein steers. J. Dairy Sci. 88:3563-3574.

Santos, J. E. P., M. Villaseñor, E. J. DePeters, P. H. Robinson, and B. C. Baldwin. 2002. Type of cottonseed and gossypol in diets of lactating dairy cows: Lactation performance and plasma gossypol. J. Dairy Sci. 85:1491-1501.

Santos, J. E. P., M. Villaseñor, E. J. DePeters, P. H. Robinson, and C. H. Holmberg. 2003. Type of cottonseed and gossypol in diets 
of lactating dairy cows: Plasma gossypol, reproduction, and health. J. Dairy Sci. 86:892-905.

Stringfellow, D. A., and S. M. Seidel. 1998. Manual of the International Embryo Transfer Society. 3rd ed. Int. Embryo Transfer Soc., Savoy, IL.

Van Soest, P. J., J. B. Robertson, and B. A. Lewis. 1991. Methods for dietary fiber, neutral detergent fiber, and nonstarch polysaccharides in relation to animal nutrition. J. Dairy Sci. 74:35833596.

Van Soom, A., M. Boerjan, M. T. Ysebaert, and A. DeKruif. 1996. Cell allocation to the inner cell mass and the trophectoderm in bovine embryos cultured in two different media. Mol. Reprod. Dev. 45:171-182.
Velasquez-Pereira, J., C. F. Aréchiga, L. R. McDowell, P. J. Hansen, P. J. Chenoweth, M. C. Calhoun, C. A. Risco, T. R. Batra, S. N. Williams, and N. S. Wilkinson. 2002. Effects of gossypol from cottonseed meal and dietary vitamin $\mathrm{E}$ on the reproductive characteristics of superovulated beef heifers. J. Anim. Sci. 80:24852492.

Velasquez-Pereira, J., L. R. McDowell, C. A. Risco, D. Prichard, F. G. Martin, M. C. Calhoun, S. N. Williams, N. S. Wilkinson, and P. Ogebe. 1998. Effects on performance, tissue integrity, and metabolism of vitamin E supplementation for beef heifers fed a diet that contains gossypol. J. Anim. Sci. 76:2871-2884.

Zirkle, S. M., Y. C. Lin, F. C. Gwazdauskas, and R. S. Canseco. 1988. Effect of gossypol on bovine embryo development during the preimplantation period. Theriogenology 30:575-582. 